\title{
Comparative plastomics of
}

\section{Amaryllidaceae: inverted repeat expansion and the degradation of the ndh genes in Strumaria truncata Jacq.}

\section{Article}

Published Version

Creative Commons: Attribution 4.0 (CC-BY)

Open Access

Könyves, K., Bilsborrow, J., Christodoulou, M. D., Culham, A. ORCID: https://orcid.org/0000-0002-7440-0133 and David, J. (2021) Comparative plastomics of Amaryllidaceae: inverted repeat expansion and the degradation of the ndh genes in Strumaria truncata Jacq. PeerJ, 9. e12400. ISSN 2167-8359 doi: https://doi.org/10.7717/peerj.12400 Available at https://centaur.reading.ac.uk/101609/

It is advisable to refer to the publisher's version if you intend to cite from the work. See Guidance on citing.

Published version at: http://dx.doi.org/10.7717/peerj.12400

To link to this article DOI: http://dx.doi.org/10.7717/peerj.12400

Publisher: PeerJ Inc

All outputs in CentAUR are protected by Intellectual Property Rights law, including copyright law. Copyright and IPR is retained by the creators or other copyright holders. Terms and conditions for use of this material are defined in the End User Agreement. 


\section{www.reading.ac.uk/centaur}

\section{CentAUR}

Central Archive at the University of Reading

Reading's research outputs online 


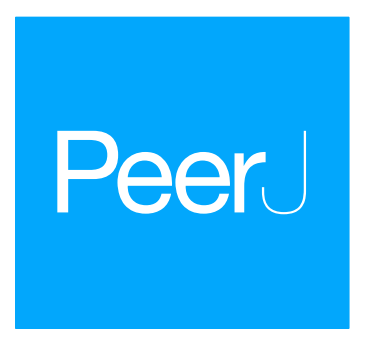

Submitted 25 June 2021

Accepted 6 October 2021

Published 12 November 2021

Corresponding author

Kálmán Könyves,

kalmankonyves@rhs.org.uk

Academic editor

Alison Nazareno

Additional Information and Declarations can be found on page 15

DOI 10.7717/peerj.12400

Copyright

2021 Könyves et al.

Distributed under

Creative Commons CC-BY 4.0

OPEN ACCESS

\section{Comparative plastomics of Amaryllidaceae: inverted repeat expansion and the degradation of the $n d h$ genes in Strumaria truncata Jacq.}

\author{
Kálmán Könyves $^{1,2}$, Jordan Bilsborrow ${ }^{2}$, Maria D. Christodoulou ${ }^{3}$, \\ Alastair Culham ${ }^{2}$ and John David ${ }^{1}$ \\ ${ }^{1}$ Royal Horticultural Society Garden Wisley, Woking, United Kingdom \\ ${ }^{2}$ Herbarium, School of Biological Sciences, University of Reading, Reading, United Kingdom \\ ${ }^{3}$ Department of Statistics, University of Oxford, Oxford, United Kingdom
}

\section{ABSTRACT}

Amaryllidaceae is a widespread and distinctive plant family contributing both food and ornamental plants. Here we present an initial survey of plastomes across the family and report on both structural rearrangements and gene losses. Most plastomes in the family are of similar gene arrangement and content however some taxa have shown gains in plastome length while in several taxa there is evidence of gene loss. Strumaria truncata shows a substantial loss of $n d h$ family genes while three other taxa show loss of cemA, which has been reported only rarely. Our sparse sampling of the family has detected sufficient variation to suggest further sampling across the family could be a rich source of new information on plastome variation and evolution.

Subjects Evolutionary Studies, Molecular Biology, Plant Science

Keywords Amaryllidaceae, IR expansion, $n d h$ loss, Strumaria

\section{INTRODUCTION}

The plastid genome, or plastome, in land plants is generally conserved in length, structure, and gene content (Wicke et al., 2011). Typical flowering plant plastomes range from 120 to $160 \mathrm{~kb}$, contain 100-120 unique genes, and have a quadripartite structure of two single copy regions (LSC and SSC) separated by two copies of the inverted repeat (IRs) (Jansen $\&$ Ruhlman, 2012; Smith \& Keeling, 2015). However, exceptions to all of these features have been found. The greatly reduced plastomes of Pilostyles range from 11-15 kb and contain only seven functioning genes (Arias-Agudelo et al., 2019). In contrast the plastome of Pelargonium $\times$ hortorum has expanded to $218 \mathrm{~kb}$ including unusually long inverted repeats (Chumley et al., 2006). Plastomes deviating from the quadripartite structure have also been reported, either without one copy of the IR (Wojciechowski et al., 2000; Sanderson et al., 2015) or incorporating the entire SSC into the inverted repeats (Sinn et al., 2018).

Rearrangements are often associated with increased repeat content in plastid genomes (Chumley et al., 2006; Haberle et al., 2008; Guisinger et al., 2011). One of the most commonly reported plastome rearrangements is the expansion or contraction of the inverted repeats. Palmer et al. (1985) and Yamada (1991) hypothesised that intramolecular 
recombination at short inverted repeats located within and around the main IR resulted in the expansion of the Chlamydomonas reinhardtii and Chlorella ellipsoidea inverted repeats, respectively, while Aii et al. (1997) proposed that recombination at forward repeats within $y c f 1$ lead to an inversion, and the IR expansion in buckwheat (Fagopyrum sp.). However, in the absence of short repeats in Nicotiana, Goulding et al. (1996) established two different mechanisms for both short, $<100 \mathrm{bp}$, and long, over $10 \mathrm{~kb}$, IR expansions: short expansions are the result of gene conversion after heteroduplex formation via Holliday junctions, and long expansions are the result of a double-strand break (DSB) in one of the IRs followed by strand invasion and repair against the other IR within the same plastome unit that progresses through the junction incorporating single-copy regions into the inverted repeats. A similar DSB repair process, but via homologous recombination at imperfect nonallelic repeats between different plastome units, resulted in the reestablishment of the IR in Medicago (Choi, Jansen \& Ruhlman, 2019). Zhu et al. (2016) attributed the IR expansions in several dicot lineages to the gene conversion mechanism. Furthermore, Wang et al. (2008) proposed that the DSB mechanism of Goulding et al. (1996) can account for shorter expansions as well, such as the development of the monocot-type IR/LSC junction by incorporating $r p s 19$ and $\operatorname{trnH}$ into the IR.

Various gene losses have occurred during the evolution of the angiosperm plastome (Raubeson \& Jansen, 2005; Jansen et al., 2007); a commonly reported example is the loss of $n d h$ genes (Song et al., 2017; Silva et al., 2018; Nevill et al., 2019). The loss of $n d h$ genes is strongly associated with a change in trophic conditions (Wicke et al., 2013; Graham, Lam \& Merckx, 2017); it represents the first step in plastome degradation in heterotrophic plants (Martin \& Sabater, 2010; Barrett \& Davis, 2012). Apart from plant lineages less reliant on photosynthesis, multiple $n d h$ gene losses have also been reported in fully photosynthetic lineages for example in aquatic/semi-aquatic plants (Iles, Smith \& Graham, 2013; Peredo, King \& Les, 2013; Folk et al., 2020), gymnosperms (Wakasugi et al., 1994; McCoy et al., 2008), Orchidaceae (Kim et al., 2015; Roma et al., 2018), and Cactaceae (Sanderson et al., 2015; Köhler et al., 2020).

Amaryllidaceae J. St.-Hil. (Saint-Hilaire, 1805) is a cosmopolitan family of bulbous geophytes and rhizomatous perennials in Asparagales (Meerow, 2000) comprising approximately 90 genera, and over 1,700 species (Meerow, Gardner \& Nakamura, 2020), in three subfamilies: Amaryllidoideae, Allioideae, and Agapanthoideae, all of which share an umbellate inflorescence. This family of petaloid monocots contains many horticulturally important genera, including: Agapanthus, Allium, Amaryllis, Clivia, Galanthus, Hippeastrum, Narcissus, and Nerine (Heywood et al., 2007). Amaryllidoideae, the most diverse subfamily with c. 75 genera (Meerow, Gardner \& Nakamura, 2020), has a complex evolutionary history, including hybridisation (García et al., 2017; Marques et al., 2017; Meerow, Gardner \& Nakamura, 2020), and morphological convergence (Meerow, 2010). Arising from our research, in horticulturally important Amaryllidaceae genera (Könyves et al., 2018; Könyves et al., 2019a; David \& Könyves, 2019), here we report the sequencing and assembly of five Amaryllidoideae species and compare our assemblies with available Amaryllidaceae plastomes from GenBank. This will broaden the knowledge, and reporting, of plastome structural variation in Amaryllidaceae. 


\section{MATERIALS \& METHODS}

Fresh leaf material was collected from five Amaryllidoideae species at RHS Garden Wisley, UK or from a private collection (Table 1). Our sampling was fundamentally opportunistic, including Amaryllidoideae species that were growing at the time of collection, and related to other projects we were working on (Könyves et al., 2018; Könyves et al., 2019a; David \& Könyves, 2019). It did, however, broaden the generic level sampling of the subfamily because these genera were chosen to act as outgroups to other, generic-level studies. Herbarium voucher specimens were deposited at WSY. Total genomic DNA was extracted using the QIAGEN DNeasy Plant Mini Kit (QIAGEN, Manchester, UK). Library development and $150 \mathrm{bp}$ PE (paired-end) sequencing on an Illumina HiSeq 4000 lane was done by the Oxford Genomics Centre (Oxford, UK). The plastomes were assembled with Fast-Plast v1.2.6 (McKain \& Wilson, 2017) and NOVOPlasty v2.7.0 (Dierckxsens, Mardulyn \& Smits, 2017). Fast-Plast assemblies were run with a total of $5 \mathrm{M}, 10 \mathrm{M}, 20 \mathrm{M}$ reads (i.e., 2.5M, $5 \mathrm{M}, 10 \mathrm{M}$ PE reads) and with all available reads. Reads were trimmed to remove NEB-PE adapter sequences. Bowtie reference indices were built with the published Narcissus poeticus plastome (MH706763). For the NOVOPlasty assemblies, adapters were trimmed with Trimmomatic v0.36 (Bolger, Lohse \& Usadel, 2014), using the same adapter sequences. An $n d h F$ sequence of Na. poeticus (KT124416) was used as the starting seed and memory was limited to $8 \mathrm{~Gb}$. All other parameters were unchanged. The Strumaria truncata NOVOPlasty assembly failed with the $n d h F$ seed, a trnK/matK sequence of $\mathrm{Na}$. poeticus (KC238498) was used instead. Among those assemblies that did not produce consistent results across the different assembly strategies, the large single copy (LSC), the small single copy (SSC), and two inverted repeat (IR) regions were identified in the final Fast-Plast contig and NOVOPlasty assemblies, and the circular plastome was assembled by hand using Geneious v11.1.5 (http:/www.geneious.com; Kearse et al., 2012). The junctions of the inverted repeats and the $n d h$ gene sequences in the S. truncata plastome assembly were confirmed by Sanger sequencing using the primers and PCR protocols detailed in Tables S1 and S2. Coverage analysis of the finished plastomes were done in Fast-Plast. The complete plastomes were annotated by transferring equivalent annotations from the $\mathrm{Na}$. poeticus plastome using Geneious v11.1.5. Gene and exon boundaries were corrected by hand when necessary.

The plastomes constructed in this study were combined with ten plastomes representing all three subfamilies of Amaryllidaceae, and a further two Asparagales (Asparagaceae and Asphodelaceae) plastomes from GenBank (Table 1). Sixty-seven coding genes (CDS) that are shared between all samples were extracted from the whole plastomes and aligned with the MUSCLE algorithm v3.8.425 using the default parameters in Geneious Prime 2020.0.5 (http://www.geneious.com). Prior to alignment, annotations of GenBank sequences were amended to correct reading frames, where necessary (changes listed in Table S3). The alignments of the 67 CDS were concatenated into a matrix of 58,230 bp. A maximum likelihood estimate of phylogeny was conducted with RAxML v8.2.11 (Stamatakis, 2014) within Geneious Prime using 1000 bootstrap replicates according to the best-fit model of evolution, GTR+I+G, identified by jModelTest 2 (Guindon \& Gascuel, 2003; Darriba et al., 2012). 
Table 1 Source information and GenBank accession numbers of the samples included in this study. Herbarium voucher codes (WSY) and publications are listed when available.

\begin{tabular}{|c|c|c|}
\hline Species & GenBank acc. no. & Source \\
\hline $\begin{array}{l}\text { Acis autumnalis var. oporantha (Jord. \& Fourr.) Lledó, } \\
\text { A.P.Davis \& M.B.Crespo }\end{array}$ & MN539611 & This study (WSY0153095) \\
\hline Lapiedra martinezii Lag. & MN539612 & This study (WSY0153095) \\
\hline Nerine sarniensis (L.) Herb. & MN539613 & This study (WSY0153096) \\
\hline Pancratium maritimum $\mathrm{L}$. & MN539614 & This study (WSY0153097) \\
\hline Strumaria truncata Jacq. & MN539615 & This study (WSY0153098) \\
\hline Clivia miniata (Lindl.) Verschaff. & MN857162 & GenBank (Wang et al., 2020) \\
\hline Hippeastrum rutilum (Ker Gawl.) Herb. & MT133568 & GenBank (Huang, 2020) \\
\hline Leucojum aestivum $\mathrm{L}$. & MH422130 & GenBank (Li et al., 2018) \\
\hline Lycoris radiata (L’Hér.) Herb. & MN158120 & GenBank (Zhang et al., 2019) \\
\hline Lycoris squamigera Maxim. & MH118290 & GenBank (Jin et al., 2018) \\
\hline Narcissus poeticus L. & MH706763 & GenBank (Könyves et al., 2018) \\
\hline Allium altaicum Pall. & MH159130 & GenBank ( Filyushin et al., 2018) \\
\hline Allium fistulosum L. & MH926357 & GenBank (Yusupov et al., 2019) \\
\hline Allium praemixtum Vved. & MK411817 & GenBank (Yusupov et al., 2021) \\
\hline Agapanthus coddii F.M.Leight. & KX790363 & GenBank (unpublished) \\
\hline Hesperoyucca whipplei (Torr.) Trel. & KX931459 & GenBank (McKain et al., 2016) \\
\hline Hemerocallis fulva (L.) L. & MG914655 & GenBank (Lee et al., 2019) \\
\hline
\end{tabular}

The inverted repeat boundaries for all samples were identified using the Repeat Finder v1.0.1 plugin in Geneious Prime, with default settings. We classified the plastomes into three groups (Type A, B, C) based on the $5^{\prime}$ portion of $y c f 1$ present in $I_{A}$, i.e., the structure of the $I_{A}-S S C$ junction $\left(J_{S A}\right)$, to identify IR expansion events. We did not identify any inversions in the plastomes therefore we tested whether the $\mathrm{IR}_{\mathrm{A}}-\mathrm{SSC}$ expansions could have happened through recombination at short inverted repeats present, i.e., the mechanism proposed by Palmer et al. (1985) and Yamada (1991), or through short forward repeats which could mediate recombination as mentioned by Choi, Jansen \& Ruhlman (2019). We searched for short repeats present in both target regions in each species of interest, detailed below, using the Repeat Finder v1.0.1 plugin in Geneious Prime with a minimum of 16 bp length and allowing 10\% mismatch. We chose the minimum length and allowed for mismatches as Staub \& Maliga (1994) showed evidence of recombination at such repeats in plastids. In Na. poeticus and Pancratium maritimum (plastome Type B) we screened the region $500-1,500 \mathrm{bp}$ from the $5^{\prime}$ end of $y c f 1$ (the position where $\mathrm{J}_{\mathrm{SA}}$ in Type A plastomes occurs, see Figs. 1 and 2) and the 500 bp either side of $\mathrm{J}_{\mathrm{SA}}$ in both species. Repeat Finder did not identify any repeats in $\mathrm{Na}$. poeticus so we manually checked the target regions for those homologous with P. maritimum to see if this lack is due to our strict search settings. To further investigate the loss of the $n d h$ genes in S. truncata, we screened for the repeats in Nerine sarniensis as well, $500 \mathrm{bp}$ either side of $\mathrm{J}_{\mathrm{SA}}$ and within $n d h H$, where $\mathrm{J}_{\mathrm{SA}}$ in $S$. truncata is found. The inverted repeat in $S$. truncata contains a 45 bp region downstream of the $n d h H$ pseudogene that is absent in other taxa. To identify where this $45 \mathrm{bp}$ region originated we aligned a portion of the $S$. truncata plastome, spanning from $t r n N$ in $\operatorname{IR}_{\mathrm{B}}$ to 

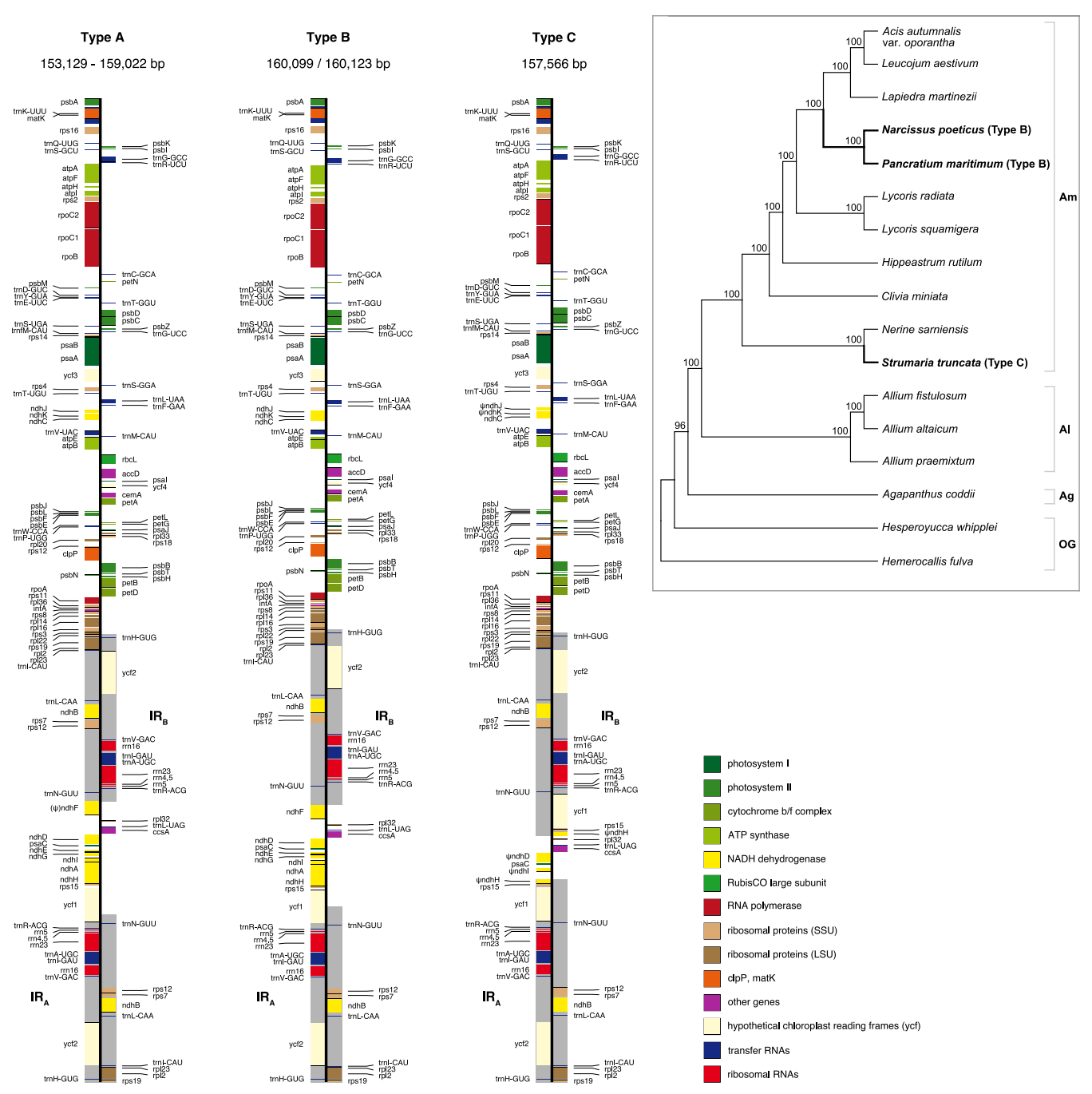

Figure 1 Maps of the three types of plastomes characterised by the $5^{\prime}$ portion of $y c f 1$ present in $\operatorname{IR}_{\mathrm{A}}$. Gray shading highlights the IR regions. Genes are coloured according to functional groups shown in the legend. Inset panel shows the relationship between the sampled species based on the RAxML analysis of 67 coding sequences. Bootstrap support values are shown at nodes. Type B and C plastomes are highlighted in bold, all other samples had Type A plastomes. Amaryllidaceae subfamilies are indicated on the right: Am, Amaryllidoideae; Al, Alliodideae; Ag, Agapanthodieae; OG, Outgroups.

Full-size DOI: 10.7717/peerj.12400/fig-1

$\operatorname{trnN}$ in $\mathrm{IR}_{\mathrm{A}}$, against the same portion of the Ne. sarniensis assembly using the MUSCLE algorithm with the default parameters in Geneious Prime. We identified tandem repeats using Phobos v3.3.12 (Mayer, 2006-2010), within Geneious Prime, following Joyce et al. (2019), by restricting the search to perfect repeats between 2 and 1,000 bp long, with the "remove hidden repeats" setting enabled.

Protein coding genes were categorised as intact, putatively pseudogenised, or lost following Joyce et al. (2019). Briefly, genes were annotated as putative pseudogenes if they contained internal stop codons, or the stop codon was missing. Genes were considered lost 

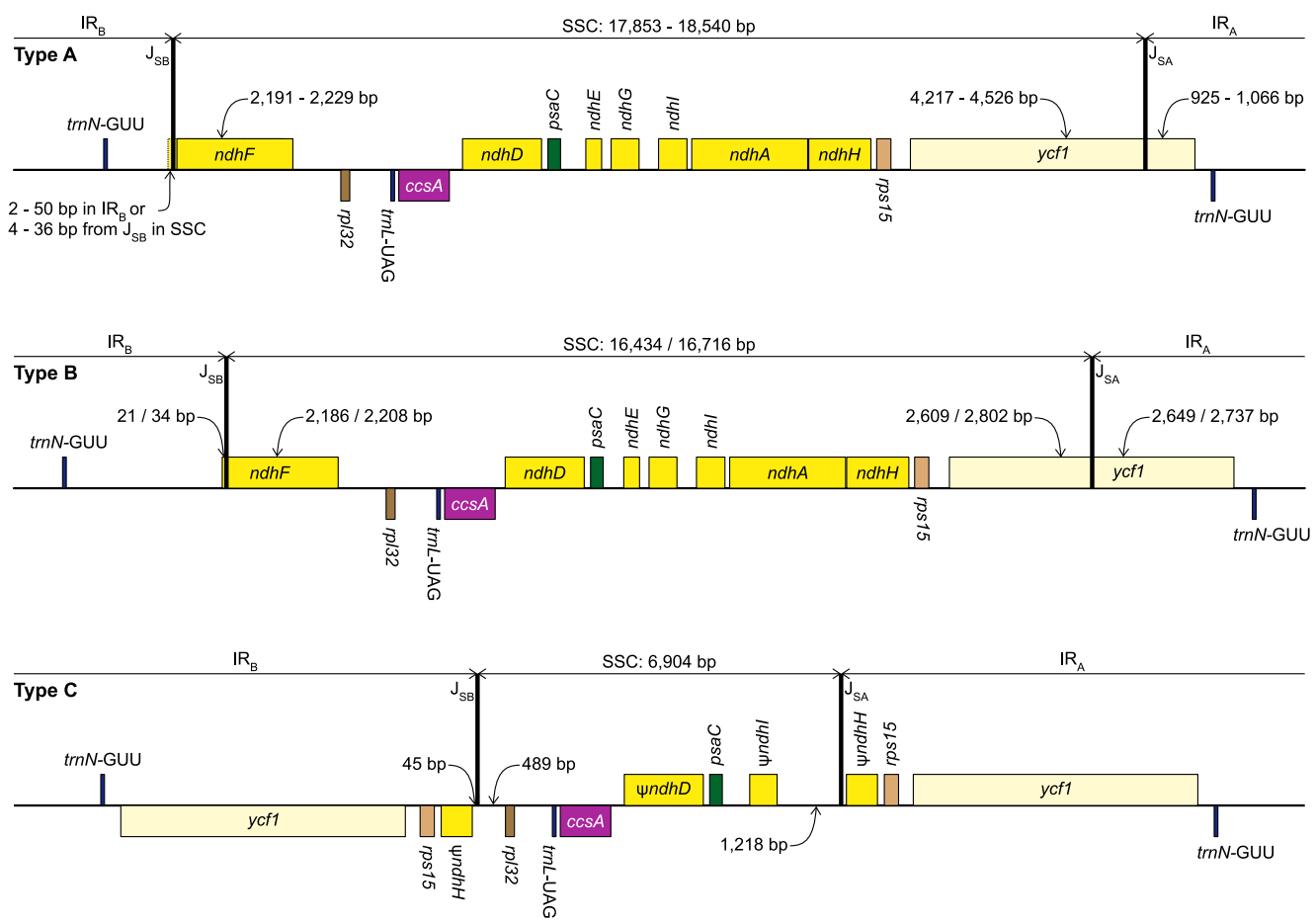

Figure 2 Structure of the junctions $\left(J_{S A}, J_{S B}\right)$ between the inverted repeats $\left(I_{A}, I_{B}\right)$ and small single copy (SSC) in the three plastome types identified in this study. The portion of genes included in the IRs and SSC is indicated. Gene order, direction of transcription, and colour code of each gene correspond to Fig. 1. $\psi$ indicates pseudogenes.

Full-size DOI: 10.7717/peerj.12400/fig-2

if less than $30 \%$ of the gene was present compared with the other samples. Plastome maps were drawn in OGDRAW v1.3.1 (Greiner et al., 2011).

\section{RESULTS}

Illumina pair-end sequencing for the samples in this study produced 19,015,437 24,547,050 raw paired-end reads. All assembly strategies produced consistent assemblies for P. maritimum. Fast-Plast with 20M reads and NOVOPlasty assemblies for Acis autumnalis var. oporantha were congruent. Variation in strategies for assembly for all other plastomes caused differences in overall length (Table S4), likely due to differing assembly of repeat rich regions. Notwithstanding, the structural parts of the plastome (LSC-IR-SSC) and expected genes could be identified in all output files, therefore final assemblies were constructed by hand. Sanger sequencing confirmed that the junctions in all five plastomes and the $n d h$ genes in S. truncata were correctly assembled. Average coverage of the final assemblies ranged from $786 \times$ to $1,379 \times$ (Table S4). Raw sequence data are available in SRA (BioProject: PRJNA730513); assembled plastomes are available on GenBank (MN539611-MN539615). Amaryllidaceae plastomes (Fig. 1) have a quadripartite structure, range from 153,129 to $160,123 \mathrm{bp}$ in length, and contain $70-86$ protein coding genes, 38 tRNAs and 8 rRNAs (Table 2). 
Table 2 Comparison of plastome features in Amaryllidaceae and outgroup samples. Plastomes assembled in this study are in bold.

\begin{tabular}{|c|c|c|c|c|c|c|c|c|c|c|c|c|c|c|c|c|c|}
\hline & \multicolumn{15}{|c|}{ Amaryllidaceae } & \multirow{2}{*}{ Asparagaceae } & \multirow[t]{2}{*}{ Asphodelaceac } \\
\hline & \multicolumn{11}{|c|}{ Amaryllidoideae } & \multicolumn{3}{|c|}{ Allioideae } & \multirow[b]{2}{*}{$\begin{array}{l}\begin{array}{l}\text { Agapanthus } \\
\text { coddii }\end{array} \\
\text { cols }\end{array}$} & & \\
\hline & $\begin{array}{l}\text { Acis } \\
\text { autumnalis } \\
\text { var. } \\
\text { oporantha }\end{array}$ & $\begin{array}{l}\text { Lapiedra } \\
\text { martinezii }\end{array}$ & $\begin{array}{l}\text { Nerine } \\
\text { sarniensis }\end{array}$ & $\begin{array}{l}\text { Pancratium } \\
\text { maritimum }\end{array}$ & $\begin{array}{l}\text { Strumaria } \\
\text { truncata }\end{array}$ & $\begin{array}{l}\text { Clivia } \\
\text { miniata }\end{array}$ & $\begin{array}{l}\text { Hippeastrum } \\
\text { rutilum }\end{array}$ & $\begin{array}{l}\text { Leucojum } \\
\text { aestivum }\end{array}$ & $\begin{array}{l}\text { Lycoris } \\
\text { radiata }\end{array}$ & $\begin{array}{l}\text { Lycoris } \\
\text { squamigera }\end{array}$ & $\begin{array}{l}\text { Narcissus } \\
\text { poeticus }\end{array}$ & $\begin{array}{l}\text { Allium } \\
\text { altaicum }\end{array}$ & $\begin{array}{l}\text { Allium } \\
\text { fistulosum }\end{array}$ & $\begin{array}{l}\text { Allium } \\
\text { praemixtum }\end{array}$ & & $\begin{array}{l}\text { Hesperoyucca } \\
\text { whipplei }\end{array}$ & $\begin{array}{l}\text { Hemerocallis } \\
\text { fulva }\end{array}$ \\
\hline $\begin{array}{l}\text { GenBank accession } \\
\text { number }\end{array}$ & MN539611 & MN539612 & MN539613 & MN539614 & MN539615 & MN857162 & MT133568 & MH422130 & MN158120 & MH118290 & MH706763 & MH159130 & MH926357 & MK411817 & KX790363 & КХ931459 & MG914655 \\
\hline $\begin{array}{l}\text { Total plastome } \\
\text { length (bp) }\end{array}$ & 157,839 & 159,022 & 158,312 & 160,123 & 157,566 & 158,114 & 158,357 & 157,241 & 158,335 & 158,459 & 166,099 & 153,129 & 153,164 & 153,226 & 157,055 & 157,832 & 155,855 \\
\hline LSC length (bp) & 85,792 & 86,756 & 86,271 & 86,393 & 85,648 & 86,204 & 86,451 & 85,657 & 86,613 & 86,431 & 86,445 & 82,196 & 82,237 & 82,162 & 85,204 & 86,170 & 84,607 \\
\hline SSC length (bp) & 18,367 & 18,540 & 18,455 & 16,716 & 6,904 & 18,334 & 18,272 & 18,180 & 18,262 & 18,500 & 16,434 & 17,913 & 17,907 & 18,042 & 18,113 & 18,228 & 18,508 \\
\hline IR length (bp) & 26,840 & 26,863 & 26,793 & 28,507 & 32,507 & 26,788 & 26,817 & 26,702 & 26,730 & 26,764 & 28,610 & 26,510 & 26,510 & 26,511 & 26,869 & 26,717 & 26,370 \\
\hline $\begin{array}{l}\text { Overall G/C } \\
\text { content }\end{array}$ & 37.7 & 37.8 & 37.8 & 37.8 & 37.8 & 38 & 37.9 & 37.9 & 37.8 & 37.8 & 37.8 & 36.8 & 36.8 & 36.8 & 37.5 & 37.8 & 37.4 \\
\hline $\begin{array}{l}\text { Number of tandem } \\
\text { repeats }\end{array}$ & 562 & 605 & 601 & 556 & 591 & 568 & 560 & 567 & 579 & 572 & 543 & 553 & 564 & 561 & 570 & 576 & 666 \\
\hline $\begin{array}{l}\text { Sum length of tandem } \\
\text { repeats (bp) }\end{array}$ & 7,017 & 7,939 & 7,922 & 6,875 & 7,591 & 7,024 & 7,021 & 7,178 & 7,140 & 7,029 & 6,838 & 7,066 & 7,267 & 7,254 & 6,975 & 7,019 & 8,790 \\
\hline $\begin{array}{l}\text { Percentage length of } \\
\text { tandem repeats }\end{array}$ & 4.45 & 4.99 & 5.00 & 4.29 & 4.82 & 4.44 & 4.43 & 4.56 & 4.51 & 4.44 & 4.12 & 4.61 & 4.74 & 4.73 & 4.44 & 4.45 & 5.64 \\
\hline $\begin{array}{l}N \text { of Intact protein } \\
\text { coding genes (unique) }\end{array}$ & $86(79)$ & $86(79)$ & $84(77)$ & $85(78)$ & $79(70)$ & 86 (79) & 86 (79) & $86(79)$ & $85^{\circ}(79)$ & 86 (79) & $85(78)$ & $85(78)$ & $85(78)$ & $85(78)$ & 86 (79) & $86(79)$ & 86 (79) \\
\hline $\begin{array}{l}\text { Pseudo protein coding } \\
\text { genes }\end{array}$ & 0 & 0 & 2 & 1 & 5 & 0 & 0 & 0 & 0 & 0 & 1 & 1 & 1 & 1 & 0 & 0 & 0 \\
\hline $\begin{array}{l}\text { Lost protein coding } \\
\text { genes }\end{array}$ & 0 & 0 & 0 & 0 & 4 & 0 & 0 & 0 & 0 & 0 & 0 & 0 & 0 & 0 & 0 & 0 & 0 \\
\hline $\begin{array}{l}\text { Nof Intact tRNA } \\
\text { (unique) }\end{array}$ & $38(30)$ & $38(30)$ & $38(30)$ & $38(30)$ & $38(30)$ & $38(30)$ & $38(30)$ & $38(30)$ & $38(30)$ & $38(30)$ & $38(30)$ & $38(30)$ & $38(30)$ & $38(30)$ & $38(30)$ & $38(30)$ & $38(30)$ \\
\hline $\begin{array}{l}\text { Nof Intact rRNA } \\
\text { (unique) }\end{array}$ & $8(4)$ & $8(4)$ & $8(4)$ & $8(4)$ & $8(4)$ & $8(4)$ & $8(4)$ & $8(4)$ & $8(4)$ & $8(4)$ & $8(4)$ & $8(4)$ & $8(4)$ & $8(4)$ & $8(4)$ & $8(4)$ & $8(4)$ \\
\hline
\end{tabular}
Notes.

${ }^{*}$ rps 19 in $\mathrm{IR}_{\mathrm{A}}$ of Lycoris radiata is truncated. 


\begin{tabular}{|c|c|c|c|c|c|}
\hline Species & Repeat sequence & Direction & $\begin{array}{l}\text { Repeat } \\
\text { length }\end{array}$ & Position & $\begin{array}{l}\text { Mismatched } \\
\text { bases }\end{array}$ \\
\hline P. maritimum & $\begin{array}{l}\text { TCATTATTAGGTTTATA - } \\
\text { TATAAACCCAATAATGA }\end{array}$ & inverted & $17 \mathrm{bp}$ & $\begin{array}{l}131,409-131,425 \\
133,062-133,078\end{array}$ & 1 \\
\hline P. maritimum & $\begin{array}{l}\text { TTCATTTTTCTCTTCTTT - } \\
\text { TTCATTTTCСТCTTCTTT }\end{array}$ & forward & $18 \mathrm{bp}$ & $\begin{array}{l}132,022-132,039 \\
133,345-13,336\end{array}$ & 1 \\
\hline Na. poeticus & $\begin{array}{l}\text { TCATTATTAGGTTTATA - } \\
\text { TATAAACCCAATAATTA }\end{array}$ & inverted & $17 \mathrm{bp}$ & $\begin{array}{l}131,379-131,395 \\
133,023-133,039\end{array}$ & 2 \\
\hline Na. poeticus & $\begin{array}{l}\text { TTCATTTTTCTCTTCTTT - } \\
\text { TTCATTTTCСТCTTCTTT }\end{array}$ & forward & $18 \mathrm{bp}$ & $\begin{array}{l}131,983-132,000 \\
133,306-133,323\end{array}$ & 1 \\
\hline
\end{tabular}

We identified three different $\mathrm{J}_{S A}$ structures (Fig. 1) in our samples. Type A was the most frequent junction type, found in 14 samples, and most plausibly the ancestral IR junction in Amaryllidaceae, as it is shared with both outgroups. The other two $\mathrm{J}_{\mathrm{SA}}$ structures show two independent IR expansion events. Type B, present in Na. poeticus and P. maritimum, is a shared IR expansion event, while Type $\mathrm{C}$ in $S$. truncata represents a different IR expansion. The $5^{\prime}$ portion of $y c f 1$ within the $\mathrm{IR}_{\mathrm{A}}$ ranged from $925-1,066 \mathrm{bp}$ for Type A (Fig. 2). The Type B plastome had 2,649 or 2,737 bp of $y c f 1$ included in $\mathrm{IR}_{\mathrm{A}}$. The IR expansion in Type $C$ has a different gene arrangement (Fig. 2): the entire $y c f 1, r p s 15$, and pseudogenised $n d h H$ were included in the IR. The IRs and the SSC ranged from 17,853 to 18,540 bp and 26,370 to $26,869 \mathrm{bp}$, respectively, in Type A plastomes. The IRs in the Type B plastomes were longer, at 28,507 or $28,610 \mathrm{bp}$, with a shorter SSC, of 16,434 or $16,716 \mathrm{bp}$. The expanded IRs in S. truncata (Type C) were the longest at 32,507 bp, while the 6,904 bp long SSC was the shortest. The arrangement of the junction between $\mathrm{SSC}$ and $\mathrm{IR}_{\mathrm{B}}$ also showed variation in Type A and Type B plastomes, however this was due to the length variation of the $3^{\prime}$ end of $n d h F$ rather than IR expansion/contraction.

Repeat Finder identified only one short inverted repeat, with our search parameters, in $P$. maritimum (Table 3). A similar repeat is present in the $\mathrm{Na}$. poeticus plastome, however this has more mismatches than the $10 \%$ threshold we set for the search. Both Type B plastomes contain the same, short, forward repeat, but in $\mathrm{Na}$. poeticus this repeat is only partially in our target region. No short repeats were identified in the S. truncata or Ne. sarniensis plastomes. Figure 3 summarises the putative mechanisms for the development of the Type $\mathrm{B}$ and $\mathrm{C}$ plastomes.

The alignment of the regions between the two copies of $\operatorname{trn} N$ encompassing the SSC from Ne. sarniensis and S. truncata showed that the 45 bp present in the S. truncata IR and the following single-copy sequence towards $r p l 32$ is homologous with the $n d h F-r p l 32$ spacer in Ne. sarniensis (Fig. S1). These 45 bp represent a second short independent IR expansion in S. truncata (Fig. 3).

The $S$. truncata plastome (Type C) showed a degradation of the $n d h$-suite (Fig. 4). Only two $n d h$-genes remained intact, $n d h B$ and $n d h C$. The $n d h A, n d h E$, $n d h F$, and $n d h G$ genes were lost, while $n d h D, n d h H, n d h I, n d h J, n d h K$ were pseudogenised. The combined length of the two putative exons of $n d h A$ is $21 \%$ of the length of $n d h A$ in other Amaryllidaceae samples. The sequence regions of the other genes classified as lost $(n d h E, n d h F, n d h G)$ 
IR expansion: Type $A$ to $B$

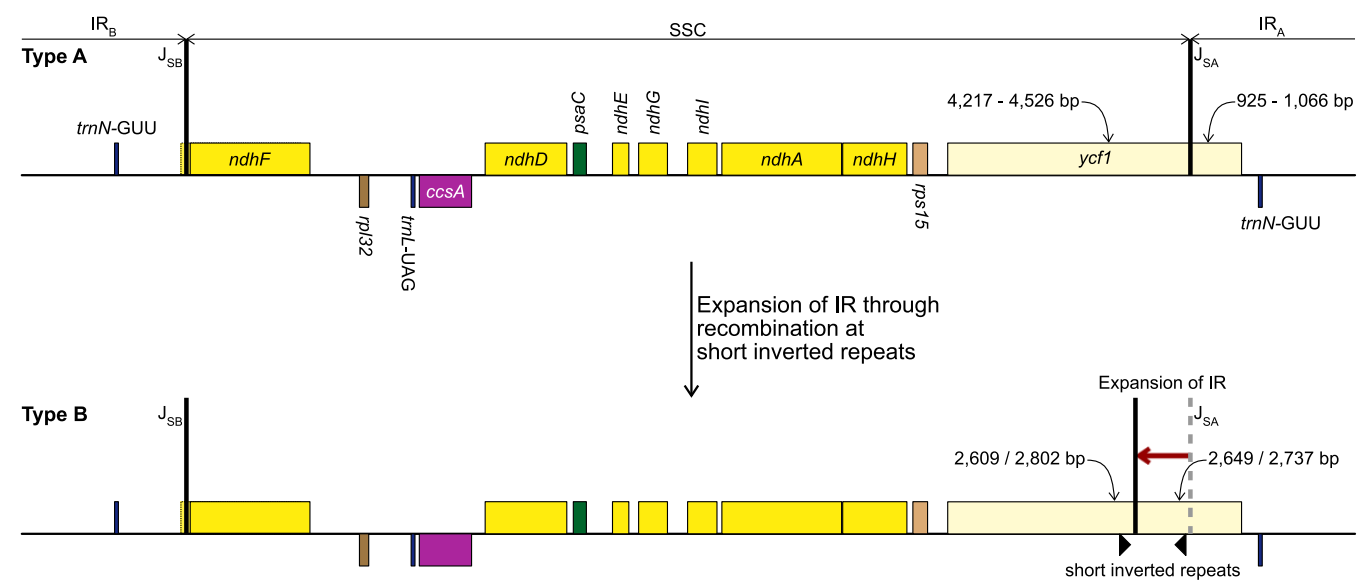

IR expansion: Type $A$ to $C$

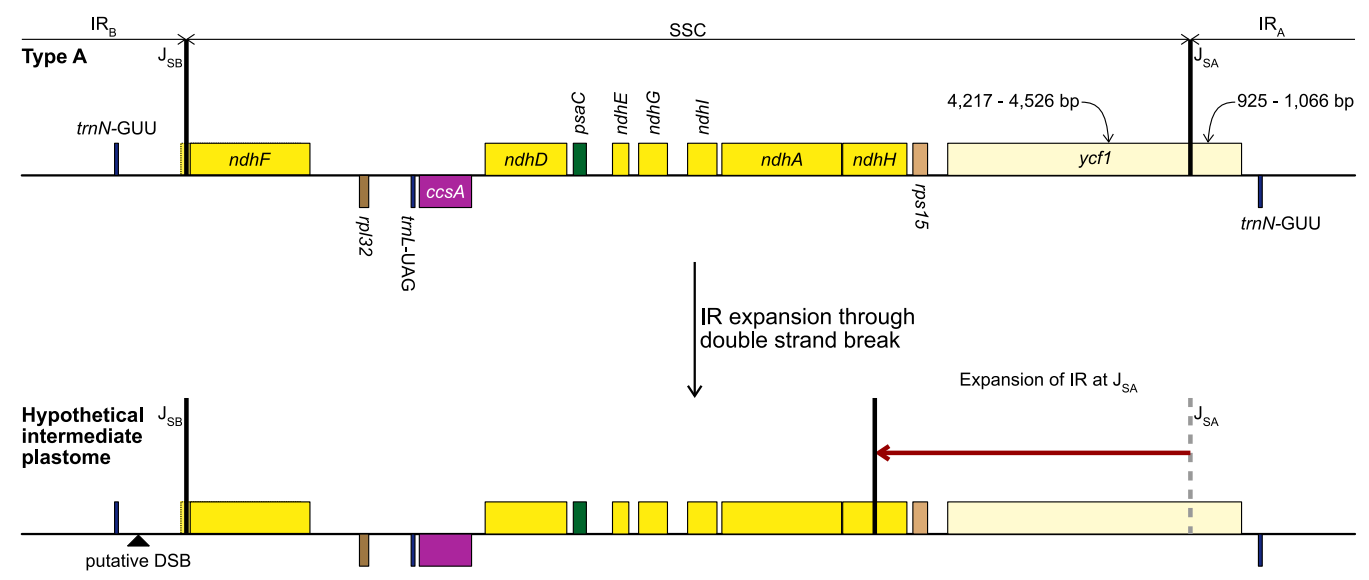

Degradation of $n d h$ genes and IR expansion through

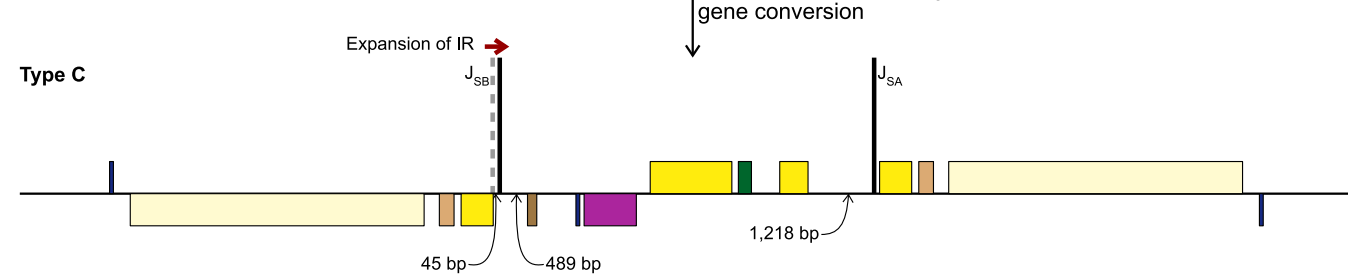

Figure 3 Development of Type B (top) and Type C (bottom) plastome from the ancestral Type A plastome. Steps required to explain the structural changes and the putative mechanisms are detailed in the figure. Gene order, direction of transcription, and colour code of each gene correspond to Fig. 1.

Full-size DOI: 10.7717/peerj.12400/fig-3 


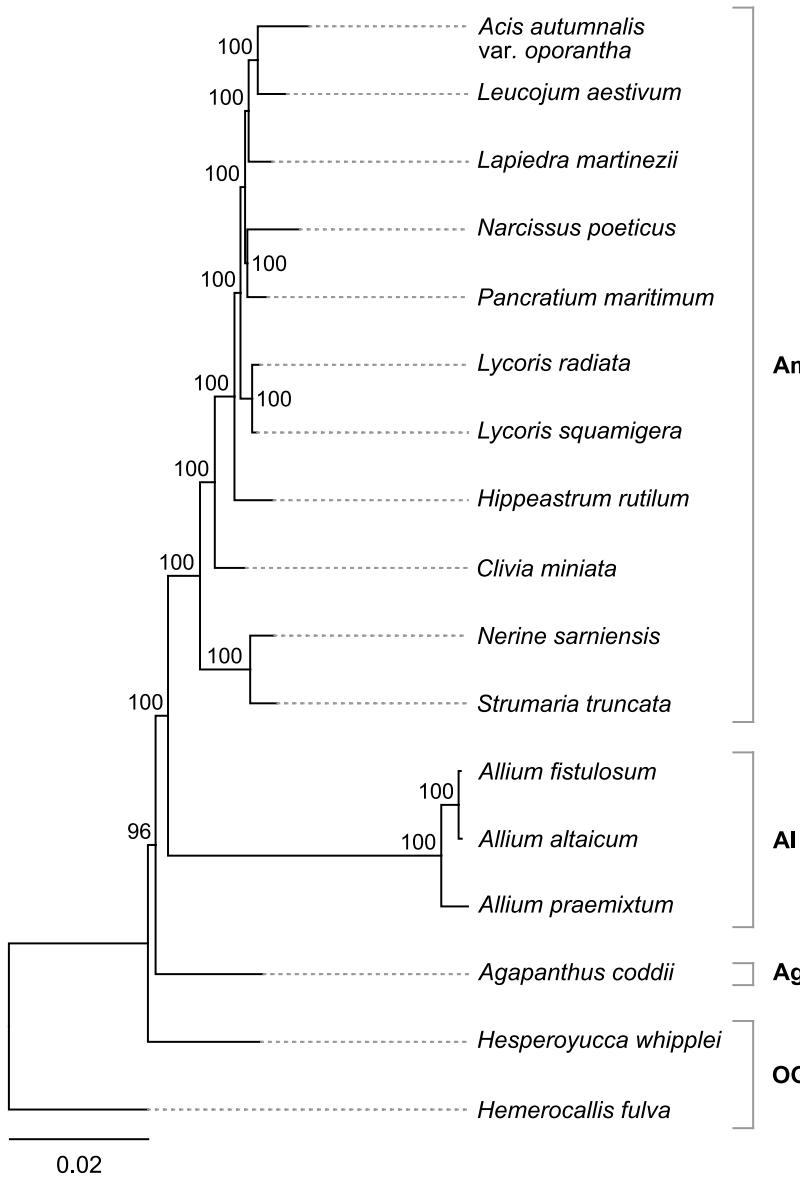

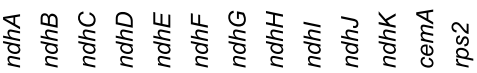

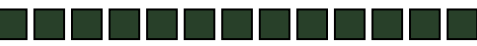

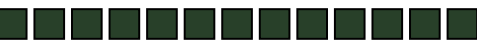

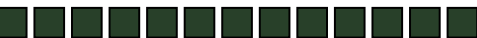

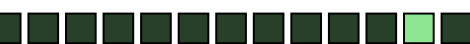
$\square \square \square \square \square \square \square \square \square \square \square \square \square$ Am $\square \square \square \square \square \square \square \square \square \square \square \square \square$ $\square \square \square \square \square \square \square \square \square \square \square \square \square$ $\square \square \square \square \square \square \square \square \square \square \square \square \square$

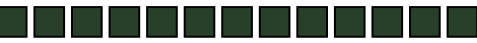
$\square \square \square \square \square \square \square \square \square \square \square \square \square$ $\square \square \square \square \square \square \square \square \square \square \square$

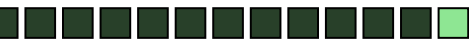
Al $\square \square \square \square \square \square \square \square \square \square \square \square \square$ $\square \square \square \square \square \square \square \square \square \square \square \square \square$

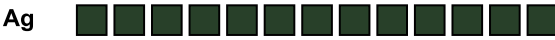
OG

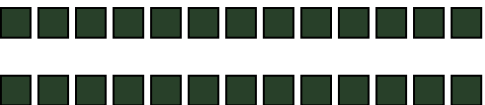
gene

Figure 4 Pattern of gene losses and pseudogenization in Amaryllidaceae and the two outgroup samples plotted against the RAxML tree based on 67 coding sequences. Bootstrap support values are shown at nodes. Plastomes assembled in this study are highlighted in bold. Amaryllidaceae subfamilies are indicated on the right: Am, Amaryllidoideae; Al, Alliodideae; Ag, Agapanthodieae; OG, Outgroups.

Full-size DOI: 10.7717/peerj.12400/fig-4

were entirely absent. The $n d h H$ gene is 1,182 bp long in Amaryllidaceae. In S. truncata, this gene is included in the IR as two putative pseudogenes, each copy is only $592 \mathrm{bp}$ long $(50 \%)$ from the start codon, and the stop codons are missing. The $n d h J$ gene contained an internal stop codon due to transversion mutation ( $\mathrm{G}$ to $\mathrm{T}$ at 49,624 bp), all other putative pseudogenes had frameshift mutations. Furthermore, $n d h F$ was classified as a putative pseudogene in Ne. sarniensis due to a missing stop codon. The $n d h C$ gene in Leucojum aestivum is missing $47 \mathrm{bp}$, including the start codon, at the $5^{\prime}$ end of the gene preceded by 2 N's, potentially indicating scaffolded contigs due to missing data. We did not categorise this gene as a putative pseudogene due to this potential missing data, however we did exclude the gene from the phylogenetic analysis. The cemA gene contains frameshift mutations in 
Na. poeticus, Ne. sarniensis, and P. maritium due to a homopolymeric A repeat at the $5^{\prime}$ end of the gene. In all Allium samples rps2 is a pseudogene.

The number of tandem repeats and their length as percentage of the total plastome ranged from 543 to 605 and $4.1 \%$ to $5.6 \%$, respectively, in Amaryllidaceae (Table 2). Tandem repeat numbers in Type A plastomes ranged from 560 to 601 (4.4-5.0\%) (Table 2). Type B plastomes had 543 (4.1\%), and 556 (4.3\%) tandem repeats in Na. poeticus and P. maritimum, respectively, and 591 (4.8\%) in S. truncata (Type C). Moreover, the highest number of repeats, 666, was found in Hemerocallis fulva, which shows no IR expansion. These changes indicate that an increased number of tandem repeats did not contribute to the IR expansions in Type B and C plastomes.

The phylogenetic analysis based on 67 protein coding genes recovered a fully resolved phylogenetic tree with maximum (100\%) bootstrap support for all branches except for the one leading to the ingroup (96\%, Fig. 4). Within Amaryllidaceae, Agapanthoideae is sister to Allioideae and Amaryllidoideae. Within Amaryllidoideae, Ne. sarniensis is sister to S. truncata and in turn they are sister to the remaining Amaryllidoideae species. Sequence alignment of the 67 protein coding genes used in the phylogenetic analysis and the resulting newick tree is available at: https://github.com/kalmankonyves/Amaryllidaceae_plastomesStrumaria.

\section{DISCUSSION}

The newly sequenced and assembled plastomes of five genera from Amaryllidoideae exhibited three plastome arrangement types based on the portion of $y c f 1$ within the inverted repeats. Previously published plastomes such as Allium (Huo et al., 2019) and Narcissus (Könyves et al., 2018) fall into our Type A and B respectively, however the Type C plastome, with the largest IR expansion, represents a novel rearrangement in Amaryllidaceae that has not been reported previously.

In typical angiosperm plastomes $\sim 1,000$ bp of $y c f 1$ is included in the IR (Sun et al., 2017). This is similar to the Type A plastome we recognised in Amaryllidaceae. We identify the Type A plastome as the ancestral state in the family, as it is shared with both outgroups (Fig. 1). The IR expansions that gave rise to the Type $\mathrm{B}$ and Type $\mathrm{C}$ plastomes represent independent events. In Na. poeticus and P. maritimum (Type B) the IR has expanded to include a larger portion of $y c f 1(2,649 / 2,737 \mathrm{bp})$, while in S. truncata (Type C) the whole of $y c f 1$ along with $r p s 15$ and a pseudogenised $n d h H$ are contained within the IR. The expansion or contraction of the inverted repeats have been shown to occur in multiple land plant lineages (Wicke et al., 2011; Jansen \& Ruhlman, 2012; Zhu et al., 2016) and can often be specific to a few genera within a family (Guisinger et al., 2011; Dugas et al., 2015; Tian et al., 2018; Thode \& Lohmann, 2019). In Asparagales IR expansions have been reported in multiple genera in Orchidaceae, incorporating genes from the SSC up to and including ccsA (Kim et al., 2015; Kim et al., 2020), and in Eustrephus latifolius, Asparagaceae (Kim, Kim \& Kim, 2016), where the IR expanded to include $y c f 1$.

Rearrangements in the plastomes have been associated with an increased number of repeats (Guisinger et al., 2011; Sinn et al., 2018). There was no correlation between the 
number of tandem repeats and IR expansion in Amaryllidaceae; the tandem repeat numbers and their length as a percentage of the total plastome (543-605; 4.1\%-5.6\%) are similar to those reported by Sinn et al. (2018) for non-rearranged plastomes (420-732; 3.3\%-6.0\%). However, we identified $17 \mathrm{bp}$ inverted repeats in the vicinity of the IR junctions in both $P$. maritimum and $\mathrm{Na}$. poeticus. We propose that the IR expansion in these species might have happened through recombination of similar short inverted repeats in the common ancestor of these genera (Fig. 3). The literature offers no consensus on how long short inverted repeats are. The earliest report by Palmer et al. (1985) for Chlamydomonas reinhardtii, identified 100-300 bp repeats in the vicinity of the IR junctions, however Aldrich et al. (1988) found 7 bp inverted repeats in Petunia and hypothesised that recombination at these repeats led to the IR expansion. We based our search for short inverted repeats on Staub \& Maliga (1994) who showed experimental evidence of recombination at $16 \mathrm{bp}$ imperfect repeats in Nicotiana tabacum resulting in extrachromosomal elements.

No short repeats were identified in the S. truncata or Ne. sarniensis plastomes. Therefore, we hypothesise that the IR expansion in S. truncata could be a result of a double-strand break repair (Fig. 3) as described by Goulding et al. (1996) in Nicotiana or homologous recombination between different plastome units could also have produced the expanded IR. Choi, Jansen \& Ruhlman (2019) proposed that short non-allelic repeats mediated recombination in Medicago resulting in the reestablishment of the inverted repeats. As we did not find any suitable repeats, the recombination instead could have happened at homologous genes as shown by Ruhlman et al. (2017) in Monsonia. It is also possible that any site of recombination could have been lost during the degradation of the $n d h$ genes. We identified a $45 \mathrm{bp}$ region downstream of the annotated $n d h H$ pseudogene to have originated in the $n d h F-r p l 32$ spacer. This indicates that the IR-SSC organisation of S. truncata is the result of two independent IR expansion events (Fig. 3). Most likely, first a double-strand break originating in $\mathrm{IR}_{\mathrm{B}}$ got repaired against the complementary strand of $\mathrm{IR}_{\mathrm{A}}$ with the copy-repair progressing beyond the $\mathrm{IR}_{\mathrm{A}}$-SSC junction incorporating $y c f 1, r p s 15$, and $592 \mathrm{bp}$ of $n d h H$ into the IR. A second small IR expansion originating in $\mathrm{IR}_{\mathrm{B}}$ further expanded the IR incorporating $45 \mathrm{bp}$ of the region upstream of rpl32 through the gene conversion mechanisms of Goulding et al. (1996). Although Goulding et al. (1996) called the mechanism responsible for short IR expansion 'gene conversion', their description: "Branch migration of a Holliday junction across an IR/LSC junction results in the formation of heteroduplex before this process stalls. Resolution of heteroduplex may then proceed by sequence correction against either strand..." does not preclude this model from applying to expansions at SC/IR junctions with non-coding sequences. Furthermore, 'gene conversion' at non-coding sequences removes the constraint of maintaining functional genes.

In S. truncata nine out of the $11 n d h$ genes have been lost or pseudogenised (Fig. 4). Loss or pseudogenisation of $n d h$ genes has been reported in Asparagales both in mycoheterotrophic and autotrophic orchids (Barrett et al., 2014; Kim et al., 2015; Kim et al., 2020; Roma et al., 2018), and in Allium paradoxum (2019). We found a further putative $n d h$ pseudogene, $n d h F$ in Ne. sarniensis, which is missing the stop codon. It is possible that this gene is functional and C-to-U RNA editing creates a stop codon at transcription. The pseudogenes in S. truncata, on the other hand, are the result of 
frameshift mutations which are not known to be edited in plastomes (Haberle et al., 2008). The $n d h$ genes encode the NADH dehydrogenase-like complex (NDH-1) which regulate photosynthetic electron transport (Peltier, Aro \& Shikanai, 2016; Shikanai, 2016). NDH-1 helps adapt photosynthesis under photooxidative stress conditions (Martin \& Sabater, 2010) and in environments with fluctuating light intensity (Yamori \& Shikanai, 2016). The loss of the $n d h$ complex has been reported in plants growing either in high or low light level environments, for example hot desert (Sanderson et al., 2015), submersed (Peredo, King \& Les, 2013), or understorey habitats (Graham, Lam \& Merckx, 2017; Omelchenko et al., 2020). Furthermore, under optimal growth conditions $n d h$ genes appear dispensable (Burrows et al., 1998; Endo et al., 1999; Rumeau, Peltier \& Cournac, 2007), and their function could also be assumed by an alternate nuclear encoded system (Wicke et al., 2011) e.g., the AA-sensitive CEF pathway (Sanderson et al., 2015). In the presence of an alternate system, the degradation of the $n d h$ genes can have little consequence on plant fitness and mutations can freely accumulate leading to pseudogenisation and loss. Alternatively, $n d h$ genes can be transferred to the nucleus and only lost from the plastome, as Roma et al. (2018) showed in Ophrys. The data we present in this paper, shallow sequencing of whole genomes (e.g., $\sim 6.3 \mathrm{~Gb}$ of raw sequence data represent $\sim 0.3-0.5 \times$ coverage of the nuclear genome of Ne. sarniensis: 12.6/19.4 Gb; Leitch et al. (2019)), allows us to simply hypothesise the fate of pseudogenised and lost genes. The loss of $n d h$ genes from the S. truncata plastome compared with Ne. sarniensis could be the result of ecological adaptation, as the two species occur in different habitats: S. truncata inhabits the semi-arid Succulent Karoo, while Ne. sarniensis occurs in the Fynbos, characterised by a wetter, Mediterranean-type climate (Duncan, Jeppe e Voigt, 2020). It is also possible that the loss of the $n d h$ genes is a result of a transfer to the nucleus, or the presence of an alternate system. Further sampling of Strumaria and Nerine species and investigating the nuclear genome and transcriptome will be necessary to identify potential routes of gene loss from the plastome.

Kim et al. (2015) and Kim et al. (2020) showed a correlation between the presence of $n d h F$ and the organisation of the IR-SSC junctions in Orchidaceae, and proposed that the loss of $n d h F$ leads to destabilisation of the IR-SSC junctions. This holds true to Najas flexilis, mentioned by Kim et al. (2015), and could be supported by our results. However, there is also published evidence that IR expansion can happen without the loss of $n d h$ genes: plastomes in Thymelaeaceae have all SSC genes, apart from $n d h F$ and $r p l 32$, incorporated in the IR in the presence of a full set of $11 \mathrm{ndh}$ genes (Könyves et al., 2019b; Lee et al., 2020; Liang, Xie \& Yan, 2020), and in Asarum the IR expanded to encompass the whole of the SSC without the loss of $n d h$ genes (Sinn et al., 2018).

The IR expansion in S. truncata is plausibly the result of two independent events, therefore the order in which gene losses and expansions happened are difficult to unravel. It is perhaps more parsimonious to suggest that the degradation of the $n d h$ genes or at least the loss of $n d h F$ preceded the second IR expansion in S. truncata, otherwise the whole of $n d h F$ had to be incorporated into the IR and subsequently lost from both $\operatorname{IR}_{\mathrm{A}}$ and $\mathrm{IR}_{\mathrm{B}}$. Further sampling in Amaryllidoideae could help establish the sequence of gene loss and IR expansion and any correlation between these events. 
There were further pseudogenised genes found in Amaryllidaceae: the chloroplast envelope membrane protein encoding cemA is pseudogenised in Ne. sarniensis, $\mathrm{Na}$. poeticus, and P. maritimum due to a homopolymeric A repeat adjacent to the potential initiation codon. A similar pattern of pseudogenisation has been shown in Lilium spp. (Do \& Kim, 2019) and Cocos nucifera (Huang, Matzke \& Matzke, 2013). The cemA gene is not essential for photosynthesis, however in high light conditions cemA-lacking mutants of Chlamydomonas reinhardtii showed decreased photosynthetic efficacy (Rolland et al., 1997). The rps2 gene is functional in Amaryllidoideae and Agapanthus coddii but has pseudogenised due to internal stop codons in Allium, which has been reported previously by Filyushin, Beletsky \& Kochieva (2019), Omelchenko et al. (2020) and Xie et al. (2019).

The phylogenetic relationship between the subfamilies recovered in this study: Agapanthoideae sister to an Allioideae-Amaryllidoideae clade is congruent with previously published studies based on plastid DNA data (Fay et al., 2000; Givnish et al., 2005; Givnish et al., 2018; Pires et al., 2006; Seberg et al., 2012). Moreover, while our sampling represents only a small fraction of the diversity within Amaryllidoideae, the relationship within the subfamily is also broadly congruent with previous studies (Meerow et al., 2006); Rønsted et al., 2012). The long branch leading to Allium in our phylogenetic tree is also present in studies using fewer (one to four) plastid genes (Givnish et al., 2005; Seberg et al., 2012; Chen et al., 2013); the reason behind this is beyond the scope of our paper.

\section{CONCLUSIONS}

We are still very much in the discovery stage when it comes to patterns of gene loss and duplication in the plastome. Genes linked to a range of functions are implicated in plastome change however, not surprisingly, most of the genes that vary are linked to photosynthesis at one level or another. The loss of so many genes is Strumaria truncata is notable and worthy of further phylogenetic investigation through deeper taxon sampling. At this stage we are not in a position to propose driving mechanisms for the change, or whether those observed are to some extent evolutionarily neutral to the growing conditions the plants experience. While the family is characterised by bulbous geophytes, the habitats those plants occupy vary enormously from arid through mesic to seasonally inundated. Likewise, the light levels tolerated by different species vary from intense sun to quite deep shade. This paper offers a first look at the kinds of variation in plastomes that might be found across the family and indicates this will be a promising area for more detailed investigation.

\section{ACKNOWLEDGEMENTS}

We thank the High-Throughput Genomics Group at the Wellcome Trust Centre for Human Genetics for the generation of sequencing data. We would like to thank three anonymous reviewers for their feedback. 


\section{ADDITIONAL INFORMATION AND DECLARATIONS}

\section{Funding}

The authors received no external funding for this work.

Competing Interests

Alastair Culham is an Academic Editor for PeerJ.

\section{Author Contributions}

- Kálmán Könyves conceived and designed the experiments, performed the experiments, analyzed the data, prepared figures and/or tables, authored or reviewed drafts of the paper, and approved the final draft.

- Jordan Bilsborrow performed the experiments, analyzed the data, authored or reviewed drafts of the paper, and approved the final draft.

- Maria D. Christodoulou analyzed the data, authored or reviewed drafts of the paper, and approved the final draft.

- Alastair Culham and John David conceived and designed the experiments, authored or reviewed drafts of the paper, and approved the final draft.

\section{DNA Deposition}

The following information was supplied regarding the deposition of DNA sequences:

Raw sequence data are available in SRA (BioProject: PRJNA730513); assembled plastomes are available on GenBank (MN539611-MN539615).

\section{Data Availability}

The following information was supplied regarding data availability:

Sequence alignment of the 67 protein coding genes used in the phylogenetic analysis and the resulting newick tree is available at GitHub: https:/github.com/kalmankonyves/ Amaryllidaceae_plastomes-Strumaria.

\section{Supplemental Information}

Supplemental information for this article can be found online at http://dx.doi.org/10.7717/ peerj.12400\#supplemental-information.

\section{REFERENCES}

Aii J, Kishima Y, Mikami T, Adachi T. 1997. Expansion of the IR in the chloroplast genomes of buckwheat species is due to incorporation of an SSC sequence that could be mediated by an inversion. Current Genetics 31:276-279 DOI 10.1007/s002940050206.

Aldrich J, Cherney BW, Williams C, Merlin E. 1988. Sequence analysis of the junction of the large single copy region and the large inverted repeat in the petunia chloroplast genome. Current Genetics 14:487-492 DOI 10.1007/BF00521274. 
Arias-Agudelo LM, González F, Isaza JP, Alzate JF, Pabón-Mora N. 2019. Plastome reduction and gene content in New World Pilostyles (Apodanthaceae) unveils high similarities to African and Australian congeners. Molecular Phylogenetics and Evolution 135:193-202 DOI 10.1016/j.ympev.2019.03.014.

Barrett CF, Davis JI. 2012. The plastid genome of the mycoheterotrophic Corallorhiza striata (Orchidaceae) is in the relatively early stages of degradation. American Journal of Botany 99:1513-1523 DOI 10.3732/ajb.1200256.

Barrett CF, Freudenstein JV, Li J, Mayfield-Jones DR, Perez L, Pires JC, Santos C. 2014. Investigating the path of plastid genome degradation in an early-transitional clade of heterotrophic orchids, and implications for heterotrophic angiosperms. Molecular Biology and Evolution 31:3095-3112 DOI 10.1093/molbev/msu252.

Bolger AM, Lohse M, Usadel B. 2014. Trimmomatic: a flexible trimmer for Illumina sequence data. Bioinformatics 30:2114-2120 DOI 10.1093/bioinformatics/btu170.

Burrows PA, Sazanov LA, Svab Z, Maliga P, Nixon PJ. 1998. Identification of a functional respiratory complex in chloroplasts through analysis of tobacco mutants containing disrupted plastid $n d h$ genes. The EMBO Journal 17:868-876 DOI 10.1093/emboj/17.4.868.

Chen S, Kim D-K, Chase MW, Kim J-H. 2013. Networks in a large-scale phylogenetic analysis: reconstructing evolutionary history of Asparagales (Lilianae) based on four plastid genes. PLOS ONE 8:e59472 DOI 10.1371/journal.pone.0059472.

Choi I-S, Jansen R, Ruhlman T. 2019. Lost and Found: return of the inverted repeat in the legume clade defined by its absence. Genome Biology and Evolution 11:1321-1333 DOI 10.1093/gbe/evz076.

Chumley TW, Palmer JD, Mower JP, Fourcade HM, Calie PJ, Boore JL, Jansen RK. 2006. The complete chloroplast genome sequence of Pelargonium $\times$ hortorum: organization and evolution of the largest and most highly rearranged chloroplast genome of land plants. Molecular Biology and Evolution 23:2175-2190 DOI 10.1093/molbev/msl089.

Darriba D, Taboada GL, Doallo R, Posada D. 2012. jModelTest 2: more models, new heuristics and parallel computing. Nature Methods 9:772 DOI 10.1038/nmeth.2109.

David J, Könyves K. 2019. Phylogenetic analysis of the Strumariinae (Amaryllidaceae) sheds light on generic concepts in the subtribe. In: Abstracts of the Monocots VI. Natal: EDUFRN DOI 10.6084/m9.figshare.8111591.

Dierckxsens N, Mardulyn P, Smits G. 2017. NOVOPlasty: de novo assembly of organelle genomes from whole genome data. Nucleic Acids Research 45:e18 DOI 10.1093/nar/gkw955.

Do HDK, Kim J-H. 2019. The implication of plastid transcriptome analysis in petaloid monocotyledons: A case study of Lilium lancifolium (Liliaceae, Liliales). Scientific Reports 9:6662 DOI 10.1038/s41598-019-43259-7.

Dugas DV, Hernandez D, Koenen EJM, Schwarz E, Straub S, Hughes CE, Jansen RK, Nageswara-Rao M, Staats M, Trujillo JT, Hajrah NH, Alharbi NS, Al-Malki AL, Sabir JSM, Bailey CD. 2015. Mimosoid legume plastome evolution: IR expansion, 
tandem repeat expansions, and accelerated rate of evolution in clpP. Scientific Reports 5:16958 DOI 10.1038/srep16958.

Duncan G, Jeppe B, Voigt L. 2020. Field guide to the amaryllis family of Southern Africa and surrounding territories. Mpumalanga: Galley Press.

Endo T, Shikanai T, Takabayashi A, Asada K, Sato F. 1999. The role of chloroplastic $\mathrm{NAD}(\mathrm{P}) \mathrm{H}$ dehydrogenase in photoprotection. FEBS Letters 457:5-8 DOI 10.1016/s0014-5793(99)00989-8.

Fay MF, Rudall PJ, Sullivan S, Stobart KL, De Bruijn AY, Reeves G, Qamaruz-Zaman F, Hong WP, Joseph J, Hahn WJ, Conran JG, Chase MW. 2000. Phylogenetic studies of Asparagales based on four plastid DNA regions. In: Wilson KL, Morrison DA, eds. Monocots: systematics and evolution. Melbourne: CSIRO, 360-371.

Filyushin MA, Beletsky AV, Kochieva EZ. 2019. Characterization of the complete chloroplast genome of leek Allium porrum L. (Amaryllidaceae). Mitochondrial DNA Part B 4:2602-2603 DOI 10.1080/23802359.2019.1640090.

Filyushin MA, Mazur AM, Shchennikova AV, Kochieva EZ. 2018. Comparative analysis of the complete plastomes of garlic Allium sativum and bulb onion Allium cepa. Vavilov Journal of Genetics and Breeding 22:524-530 DOI 10.18699/VJ18.390.

Folk RA, Sewnath N, Xiang C-L, Sinn BT, Guralnick RP. 2020. Degradation of key photosynthetic genes in the critically endangered semi-aquatic flowering plant Saniculiphyllum guangxiense (Saxifragaceae). BMC Plant Biology 20:324 DOI 10.1186/s12870-020-02533-x.

García N, Folk RA, Meerow AW, Chamala S, Gitzendanner MA, de Oliveira RS, Soltis DE, Soltis PS. 2017. Deep reticulation and incomplete lineage sorting obscure the diploid phylogeny of rain-lilies and allies (Amaryllidaceae tribe Hippeastreae). Molecular Phylogenetics and Evolution 111:231-247 DOI 10.1016/j.ympev.2017.04.003.

Givnish TJ, Pires JC, Graham SW, McPherson MA, Prince LM, Patterson TB, Rai HS, Roalson EH, Evans TM, Hahn WJ, Millam KC, Meerow AW, Molvray M, Kores PJ, O’Brien HE, Hall JC, Kress WJ, Sytsma KJ. 2005. Repeated evolution of net venation and fleshy fruits among monocots in shaded habitats confirms a priori predictions: evidence from an $n d h F$ phylogeny. Proceedings of the Royal Society $B$ 272:1481-1490 DOI 10.1098/rspb.2005.3067.

Givnish TJ, Zuluaga A, Spalink D, Gomez MSoto, Lam VKY, Saarela JM, Sass C, Iles WJD, De Sousa DJL, Leebens-Mack J, Pires JChris, Zomlefer WB, Gandolfo MA, Davis JI, Stevenson DW, De Pamphilis C, Specht CD, Graham SW, Barrett CF, Ané C. 2018. Monocot plastid phylogenomics, timeline, net rates of species diversification, the power of multi-gene analyses, and a functional model for the origin of monocots. American Journal of Botany 105:1888-1910 DOI 10.1002/ajb2.1178.

Goulding SE, Olmstead RG, Morden CW, Wolfe KH. 1996. Ebb and flow of the chloroplast inverted repeat. Molecular \& General Genetics 252:195-206 DOI 10.1007/BF02173220. 
Graham SW, Lam VKY, Merckx VSFT. 2017. Plastomes on the edge: the evolutionary breakdown of mycoheterotroph plastid genomes. The New Phytologist 214:48-55 DOI 10.1111/nph.14398.

Greiner S, Rauwolf U, Meurer J, Herrmann RG. 2011. The role of plastids in plant speciation. Molecular Ecology 20:671-691 DOI 10.1111/j.1365-294X.2010.04984.x.

Guindon S, Gascuel O. 2003. A simple, fast, and accurate algorithm to estimate large phylogenies by maximum likelihood. Systematic Biology 52:696-704 DOI 10.1080/10635150390235520.

Guisinger MM, Kuehl JV, Boore JL, Jansen RK. 2011. Extreme reconfiguration of plastid genomes in the angiosperm family Geraniaceae: rearrangements, repeats, and codon usage. Molecular Biology and Evolution 28:583-600 DOI 10.1093/molbev/msq229.

Haberle RC, Fourcade HM, Boore JL, Jansen RK. 2008. Extensive rearrangements in the chloroplast genome of Trachelium caeruleum are associated with repeats and tRNA genes. Journal of Molecular Evolution 66:350-361 DOI 10.1007/s00239-008-9086-4.

Heywood VH, Brummitt RK, Culham A, Seberg O. 2007. Flowering plant families of the world. Ontario: Firefly Books.

Huang B. 2020. The complete chloroplast genome sequence of Hippeastrum rutilum (Amaryllidoideae). Mitochondrial DNA Part B 5:3405-3406 DOI 10.1080/23802359.2020.1820388.

Huang Y-Y, Matzke AJM, Matzke M. 2013. Complete sequence and comparative analysis of the chloroplast genome of coconut palm (Cocos nucifera). PLOS ONE 8:e74736 DOI 10.1371/journal.pone.0074736.

Huo Y, Gao L, Liu B, Yang Y, Kong S, Sun Y, Yang Y, Wu X. 2019. Complete chloroplast genome sequences of four Allium species: comparative and phylogenetic analyses. Scientific Reports 9:1-14 DOI 10.1038/s41598-019-48708-x.

Iles WJD, Smith SY, Graham SW. 2013. A well-supported phylogenetic framework for the monocot order Alismatales reveals multiple losses of the plastid NADH dehydrogenase complex and a strong long-branch effect. In: Early events in monocot evolution. Cambridge: Cambridge University Press DOI 10.1017/CBO9781139002950.002.

Jansen RK, Cai Z, Raubeson LA, Daniell H, De Pamphilis CW, Leebens-Mack J, Müller KF, Guisinger-Bellian M, Haberle RC, Hansen AK, Chumley TW, Lee S-B, Peery R, McNeal JR, Kuehl JV, Boore JL. 2007. Analysis of 81 genes from 64 plastid genomes resolves relationships in angiosperms and identifies genome-scale evolutionary patterns. Proceedings of the National Academy of Sciences of the United States of America 104:19369-19374 DOI 10.1073/pnas.0709121104.

Jansen RK, Ruhlman TA. 2012. plastid genomes of seed plants. In: Bock R, Knoop V, eds. Genomics of chloroplasts and mitochondria. Dordrecht, Netherlands: Springer, 103-126 DOI 10.1007/978-94-007-2920-9_5.

Jin SW, Park JY, Kang S-J, Park H-S, Shim H, Lee TJ, Kang JH, Sung SH, Yang T-J. 2018. The complete chloroplast genome sequence of Magic Lily (Lycoris squamigera). Mitochondrial DNA Part B 3:1210-1211 DOI 10.1080/23802359.2018.1527193.

Joyce EM, Crayn DM, Lam VKY, Gerelle WK, Graham SW, Nauheimer L. 2019. Evolution of Geosiris (Iridaceae): historical biogeography and plastid-genome 
evolution in a genus of non-photosynthetic tropical rainforest herbs disjunct across the Indian Ocean. Australian Systematic Botany 31:504-522 DOI 10.1071/SB18028.

Kearse M, Moir R, Wilson A, Stones-Havas S, Cheung M, Sturrock S, Buxton S, Cooper A, Markowitz S, Duran C, Thierer T, Ashton B, Meintjes P, Drummond A. 2012. Geneious Basic: an integrated and extendable desktop software platform for the organization and analysis of sequence data. Bioinformatics 28:1647-1649 DOI 10.1093/bioinformatics/bts199.

Kim Y-K, Jo S, Cheon S-H, Joo M-J, Hong J-R, Kwak M, Kim K-J. 2020. Plastome evolution and phylogeny of orchidaceae, with 24 new sequences. Frontiers in Plant Science 11:22 DOI 10.3389/fpls.2020.00022.

Kim HT, Kim JS, Kim J-H. 2016. The complete plastid genome sequence of Eustrephus latifolius (Asparagaceae: Lomandroideae). Mitochondrial DNA Part A 27:1549-1551 DOI 10.3109/19401736.2014.953132.

Kim HT, Kim JS, Moore MJ, Neubig KM, Williams NH, Whitten WM, Kim J-H. 2015. Seven new complete plastome sequences reveal rampant independent loss of the $n d h$ gene family across orchids and associated instability of the inverted repeat/small single-copy region boundaries. PLOS ONE 10:e0142215 DOI 10.1371/journal.pone.0142215.

Köhler M, Reginato M, Souza-Chies TT, Majure LC. 2020. Insights into chloroplast genome evolution across Opuntioideae (Cactaceae) reveals robust yet sometimes conflicting phylogenetic topologies. Frontiers in Plant Science 11:729 DOI 10.3389/fpls.2020.00729.

Könyves K, Bilsborrow J, David J, Culham A. 2018. The complete chloroplast genome of Narcissus poeticus L. (Amaryllidaceae: Amaryllidoideae). Mitochondrial DNA Part B 3:1137-1138 DOI 10.1080/23802359.2018.1521311.

Könyves K, Bilsborrow J, David J, Culham A. 2019a. Whole chloroplast genome analysis in Narcissus and its implications for our understanding of the evolution of the genus. In: Abstracts of the Monocots VI. Natal: EDUFRN DOI 10.6084/m9.figshare.8111591.

Könyves K, Yooprasert S, Culham A, David J. 2019b. The complete plastome of Daphne laureola L, (Thymelaeaceae). Mitochondrial DNA Part B 4:3364-3365 DOI 10.1080/23802359.2019.1674201.

Lee J, Lim J-S, Kim S-Y, Chun HS, Lee D, Nah G. 2019. The complete chloroplast genome of Hemerocallis fulva. Mitochondrial DNA Part B 4:2199-2200 DOI 10.1080/23802359.2019.1624214.

Lee SY, Xu K, Liao W, Fan Q. 2020. The complete chloroplast genome of Edgeworthia chrysantha (Thymelaeaceae). Mitochondrial DNA Part B 5:3657-3658 DOI 10.1080/23802359.2020.1832600.

Leitch IJ, Johnston E, Pellicer J, Hidalgo O, Bennett . 2019. Plant DNA C-values database release 7.1. Available at https://cvalues.science.kew.org/ (accessed on 30 August 2021). 
Li M-D, Wu X, Wu J-J, Zhou X, Wang R-H, Qi Z-C. 2018. Characterization of the complete chloroplast genome of summer snowflake (Leucojum aestivum, Amaryllidaceae). Mitochondrial DNA Part B 3:1069-1070 DOI 10.1080/23802359.2018.1501309.

Liang C, Xie J, Yan J. 2020. The complete chloroplast genome sequence of Stellera chamaejasme f. chrysantha (Thymelaeaceae). Mitochondrial DNA Part B 5:3269-3270 DOI 10.1080/23802359.2020.1810166.

Marques I, Aguilar JF, Martins-Louçao MA, Moharrek F, Feliner GN. 2017. A threegenome five-gene comprehensive phylogeny of the bulbous genus Narcissus (Amaryllidaceae) challenges current classifications and reveals multiple hybridization events. Taxon 66:832-854 DOI 10.12705/664.3.

Martín M, Sabater B. 2010. Plastid $n d h$ genes in plant evolution. Plant Physiology and Biochemistry 48:636-645 DOI 10.1016/j.plaphy.2010.04.009.

Mayer C. 2006-2010. Phobos 3.3.12. Available at $h t t p: / / w w w . r u b . d e / e c o e v o / c m / c m \_p h o b o s$. htm.

McCoy SR, Kuehl JV, Boore JL, Raubeson LA. 2008. The complete plastid genome sequence of Welwitschia mirabilis: an unusually compact plastome with accelerated divergence rates. BMC Evolutionary Biology 8:130 DOI 10.1186/1471-2148-8-130.

McKain MR, McNeal JR, Kellar PR, Eguiarte LE, Pires JC, Leebens-Mack J. 2016. Timing of rapid diversification and convergent origins of active pollination within Agavoideae (Asparagaceae). American Journal of Botany 103:1717-1729 DOI 10.3732/ajb.1600198.

McKain M, Wilson M. 2017. Fast-Plast: rapid de novo assembly and finishing for whole chloroplast genomes Zenodo DOI 10.5281/zenodo.973887.

Meerow AW. 2000. Phylogeny of the Amaryllidaceae: molecules and morphology. In: Wilson KL, Morrison DA, eds. Monocots: systematics and Evolution. Melbourne: CSIRO, 372-386.

Meerow AW. 2010. Convergence or reticulation? Mosaic evolution in the canalized American Amaryllidaceae. In: Diversity, phylogeny and evolution in the monocotyledons. Aarhus: Aarhus University Press, 145-168.

Meerow AW, Francisco-Ortega J, Kuhn DN, Schnell RJ. 2006. Phylogenetic relationships and biogeography within the eurasian clade of amaryllidaceae based on plastid $n d h F$ and nrDNA ITS sequences: lineage sorting in a reticulate area?. Systematic Botany 31:42-60 DOI 10.1600/036364406775971787.

Meerow AW, Gardner EM, Nakamura K. 2020. Phylogenomics of the Andean Tetraploid Clade of the American Amaryllidaceae (Subfamily Amaryllidoideae): unlocking a polyploid generic radiation abetted by continental geodynamics. Frontiers in Plant Science 11:1698 DOI 10.3389/fpls.2020.582422.

Nevill PG, Howell KA, Cross AT, Williams AV, Zhong X, Tonti-Filippini J, Boykin LM, Dixon KW, Small I. 2019. Plastome-wide rearrangements and gene losses in carnivorous droseraceae. Genome Biology and Evolution 11:472-485 DOI 10.1093/gbe/evz005. 
Omelchenko DO, Krinitsina AA, Belenikin MS, Konorov EA, Kuptsov SV, Logacheva MD, Speranskaya AS. 2020. Complete plastome sequencing of Allium paradoxum reveals unusual rearrangements and the loss of the $n d h$ genes as compared to Allium ursinum and other onions. Gene 726:144154 DOI 10.1016/j.gene.2019.144154.

Palmer JD, Boynton JE, Gillham NW, Harris EH. 1985. Evolution and recombination of the large inverted repeat in Chlamydomonas chloroplast DNA. In: Steinback KE, Bonitz S, Arntzen CJ, Bogorad L, eds. Molecular biology of the photosynthetic apparatus. New York: Cold Spring Harbor Laboratory Press, 269-278.

Peltier G, Aro E-M, Shikanai T. 2016. NDH-1 and NDH-2 plastoquinone reductases in oxygenic photosynthesis. Annual Review of Plant Biology 67:55-80 DOI 10.1146/annurev-arplant-043014-114752.

Peredo EL, King UM, Les DH. 2013. The plastid genome of Najas flexilis: adaptation to submersed environments is accompanied by the complete loss of the NDH complex in an aquatic angiosperm. PLOS ONE 8:e68591 DOI 10.1371/journal.pone.0068591.

Pires C, Maureira I, Givnish T, Systma K, Seberg O, Peterson G, Davis J, Stevenson D, Rudall P, Fay M, Chase M. 2006. Phylogeny, genome size, and chromosome evolution of asparagales. Aliso 22:287-304 DOI 10.5642/aliso.20062201.24.

Raubeson LA, Jansen RK. 2005. Chloroplast genomes of plants. In: Henry RJ, ed. Plant diversity and evolution: genotypic and phenotypic variation in higher plants. Wallingford: CABI, 45-68 DOI 10.1079/9780851999043.0045.

Rolland N, Dorne AJ, Amoroso G, Sültemeyer DF, Joyard J, Rochaix JD. 1997. Disruption of the plastid $y c f 10$ open reading frame affects uptake of inorganic carbon in the chloroplast of Chlamydomonas. The EMBO Journal 16:6713-6726 DOI 10.1093/emboj/16.22.6713.

Roma L, Cozzolino S, Schlüter PM, Scopece G, Cafasso D. 2018. The complete plastid genomes of Ophrys iricolor and O. sphegodes (Orchidaceae) and comparative analyses with other orchids. PLOS ONE 13:e0204174 DOI 10.1371/journal.pone.0204174.

Rønsted N, Symonds MRE, Birkholm T, Christensen SB, Meerow AW, Molander M, Mølgaard P, Petersen G, Rasmussen N, Van Staden J, Stafford GI, Jäger AK. 2012. Can phylogeny predict chemical diversity and potential medicinal activity of plants? A case study of Amaryllidaceae. BMC Evolutionary Biology 12:182 DOI 10.1186/1471-2148-12-182.

Ruhlman TA, Zhang J, Blazier JC, Sabir JSM, Jansen RK. 2017. Recombinationdependent replication and gene conversion homogenize repeat sequences and diversify plastid genome structure. American Journal of Botany 104:559-572 DOI 10.3732/ajb.1600453.

Rumeau D, Peltier G, Cournac L. 2007. Chlororespiration and cyclic electron flow around PSI during photosynthesis and plant stress response. Plant, Cell $\&$ Environment 30:1041-1051 DOI 10.1111/j.1365-3040.2007.01675.x.

Saint-Hilaire J-HJ. 1805. Exposition des familles naturelles et de la germination des plantes. Paris, Strasbourg: Treuttel et Würtz.

Sanderson MJ, Copetti D, Búrquez A, Bustamante E, Charboneau JLM, Eguiarte LE, Kumar S, Lee HO, Lee J, McMahon M, Steele K, Wing R, Yang T-J, Zwickl D, 
Wojciechowski MF. 2015. Exceptional reduction of the plastid genome of saguaro cactus (Carnegiea gigantea): loss of the $n d h$ gene suite and inverted repeat. American Journal of Botany 102:1115-1127 DOI 10.3732/ajb.1500184.

Seberg O, Petersen G, Davis JI, Pires JC, Stevenson DW, Chase MW, Fay MF, Devey DS, Jørgensen T, Sytsma KJ, Pillon Y. 2012. Phylogeny of the Asparagales based on three plastid and two mitochondrial genes. American Journal of Botany 99:875-889 DOI 10.3732/ajb.1100468.

Shikanai T. 2016. Chloroplast NDH: a different enzyme with a structure similar to that of respiratory NADH dehydrogenase. Biochimica Et Biophysica Acta (BBA) Bioenergetics 1857:1015-1022 DOI 10.1016/j.bbabio.2015.10.013.

Silva SR, Michael TP, Meer EJ, Pinheiro DG, Varani AM, Miranda VFO. 2018. Comparative genomic analysis of Genlisea (corkscrew plants-Lentibulariaceae) chloroplast genomes reveals an increasing loss of the ndh genes. PLOS ONE 13:e0190321 DOI 10.1371/journal.pone.0190321.

Sinn BT, Sedmak DD, Kelly LM, Freudenstein JV. 2018. Total duplication of the small single copy region in the angiosperm plastome: rearrangement and inverted repeat instability in Asarum. American Journal of Botany 105:71-84 DOI 10.1002/ajb2.1001.

Smith DR, Keeling PJ. 2015. Mitochondrial and plastid genome architecture: reoccurring themes, but significant differences at the extremes. Proceedings of the National Academy of Sciences of the United States of America 112:10177-10184 DOI 10.1073/pnas.1422049112.

Song Y, Yu W-B, Tan Y, Liu B, Yao X, Jin J, Padmanaba M, Yang J-B, Corlett RT. 2017. Evolutionary comparisons of the chloroplast genome in lauraceae and insights into loss events in the magnoliids. Genome Biology and Evolution 9:2354-2364 DOI 10.1093/gbe/evx180.

Stamatakis A. 2014. RAxML version 8: a tool for phylogenetic analysis and post-analysis of large phylogenies. Bioinformatics 30:1312-1313 DOI 10.1093/bioinformatics/btu033.

Staub JM, Maliga P. 1994. Extrachromosomal elements in tobacco plastids. Proceedings of the National Academy of Sciences of the United States of America 91:7468-7472 DOI 10.1073/pnas.91.16.7468.

Sun Y, Moore MJ, Lin N, Adelalu KF, Meng A, Jian S, Yang L, Li J, Wang H. 2017. Complete plastome sequencing of both living species of Circaeasteraceae (Ranunculales) reveals unusual rearrangements and the loss of the $n d h$ gene family. BMC Genomics 18:592 DOI 10.1186/s12864-017-3956-3.

Thode VA, Lohmann LG. 2019. Comparative chloroplast genomics at low taxonomic levels: a case study using Amphilophium (Bignonieae, Bignoniaceae). Frontiers in Plant Science 10:796 DOI 10.3389/fpls.2019.00796.

Tian N, Han L, Chen C, Wang Z. 2018. The complete chloroplast genome sequence of Epipremnum aureum and its comparative analysis among eight Araceae species. PLOS ONE 13:e0192956 DOI 10.1371/journal.pone.0192956.

Wakasugi T, Tsudzuki J, Ito S, Nakashima K, Tsudzuki T, Sugiura M. 1994. Loss of all $n d h$ genes as determined by sequencing the entire chloroplast genome of the black 
pine Pinus thunbergii. Proceedings of the National Academy of Sciences of the United States of America 91:9794-9798 DOI 10.1073/pnas.91.21.9794.

Wang R-J, Cheng C-L, Chang C-C, Wu C-L, Su T-M, Chaw S-M. 2008. Dynamics and evolution of the inverted repeat-large single copy junctions in the chloroplast genomes of monocots. BMC Evolutionary Biology 8:36 DOI 10.1186/1471-2148-8-36.

Wang W, Zhang F, Li C, Zhou X. 2020. The complete chloroplast genome of Clivia miniata. Mitochondrial DNA Part B 5:1011-1012 DOI 10.1080/23802359.2020.1721033.

Wicke S, Müller KF, De Pamphilis CW, Quandt D, Wickett NJ, Zhang Y, Renner SS, Schneeweiss GM. 2013. Mechanisms of functional and physical genome reduction in photosynthetic and nonphotosynthetic parasitic plants of the broomrape family. The Plant Cell 25:3711-3725 DOI 10.1105/tpc.113.113373.

Wicke S, Schneeweiss GM, De Pamphilis CW, Müller KF, Quandt D. 2011. The evolution of the plastid chromosome in land plants: gene content, gene order, gene function. Plant Molecular Biology 76:273-297 DOI 10.1007/s11103-011-9762-4.

Wojciechowski MF, Sanderson MJ, Steele KP, Liston A. 2000. Molecular phylogeny of the temperate herbaceous tribes of papilionoid legumes: a supertree approach. In: Herendeen PS, Bruneau A, eds. Advances in Legume Systematics 9. Kew: Royal Botanic Gardens, 277-298.

Xie D-F, Yu H-X, Price M, Xie C, Deng Y-Q, Chen J-P, Yu Y, Zhou S-D, He X-J. 2019. Phylogeny of Chinese Allium species in section Daghestanica and adaptive evolution of Allium (Amaryllidaceae, Allioideae) species revealed by the chloroplast complete genome. Frontiers in Plant Science 10:460 DOI 10.3389/fpls.2019.00460.

Yamada T. 1991. Repetitive sequence-mediated rearrangements in Chlorella ellipsoidea chloroplast DNA: completion of nucleotide sequence of the large inverted repeat. Current Genetics 19:139-147 DOI 10.1007/BF00326295.

Yamori W, Shikanai T. 2016. Physiological functions of cyclic electron transport around photosystem I in sustaining photosynthesis and plant growth. Annual Review of Plant Biology 67:81-106 DOI 10.1146/annurev-arplant-043015-112002.

Yusupov Z, Deng T, Liu C, Lin N, Tojibaev K, Sun H. 2019. The complete chloroplast genome of Allium fistulosum. Mitochondrial DNA Part B 4:489-490 DOI 10.1080/23802359.2018.1545532.

Yusupov Z, Deng T, Volis S, Khassanov F, Makhmudjanov D, Tojibaev K, Sun H. 2021. Phylogenomics of Allium section Cepa (Amaryllidaceae) provides new insights on domestication of onion. Plant Diversity 43:102-110 DOI 10.1016/j.pld.2020.07.008.

Zhang F, Shu X, Wang T, Zhuang W, Wang Z. 2019. The complete chloroplast genome sequence of Lycoris radiata. Mitochondrial DNA Part B 4:2886-2887 DOI 10.1080/23802359.2019.1660265.

Zhu A, Guo W, Gupta S, Fan W, Mower JP. 2016. Evolutionary dynamics of the plastid inverted repeat: the effects of expansion, contraction, and loss on substitution rates. The New Phytologist 209:1747-1756 DOI 10.1111/nph.13743. 